\title{
Torture and the medical profession: a review
}

\author{
Peter Vesti and Niels Johan Lavik Copenhagen, Denmark and Oslo, Norway, respectively
}

\section{Introduction}

Current knowledge about doctor participation in torture was reviewed at the symposium Torture and the Medical Profession. This particular topic has received increasing attention during the last few years, and the meeting may be seen as one in a series, following particularly Doctors, Ethics, and Torture in Copenhagen, 1986 and Physicians, Ethics, and Torture in Montevideo $1987(1,2)$.

The background for the meeting, as well as the recommendations emanating from it, are reviewed, including the call for an international tribunal to evaluate doctors alleged to have been involved in torture.

\section{Historical background}

Throughout the history of man, new knowledge has always been used in a social context either to improve the circumstances of some, or most, members of the group, or to subdue outsiders, within or outside of the group, for example persecution and wars.

The dawning scientific understanding of the human body during the Middle Ages was also employed for both purposes. Anatomy, for instance, was applied to help ill citizens - the early lithotomists are an example of this - but at the same time it was used by executioners during judicial torture to prolong the suffering of the condemned, perhaps, for example by impalement - torture or killing by transfixing the body on a pointed stake $(3,4)$.

During the 15th and 16th centuries, when medical knowledge became the province of a new kind of scientifically trained doctor, the same principles were carried forward. The doctor treated the sick and participated in judicial interrogation under torture and executions provided for in secular as well as ecclesiastical law $(5,6,7)$. The doctor, by his participation, not only oversaw the physical state of the accused or condemned but, as a representative of authority, he also legitimised the torture and the executions.

Doctor participation in torture is mentioned frequently enough in historical material to indicate it was a regular occurrence.

Torture declined in Europe during the 19th century but re-emerged during World War II $(8,9)$, when $\vec{V}$ doctors participated in torture and genocide both in Europe and in the Far East. At the war crimes' trials only a limited number of doctors were prosecuted. The extent of doctor participation, direct or indirect, was only revealed later $(10,11)$. It brings about strong emotions even today (12).

After the war, doctors regularly participated in torture during the wars of liberation, for example in Africa, during the application of 'brainwashing' in Eastern Europe, and during the era of European dictatorships, for example on the Iberian peninsuld $(13,14,15,16,17)$. Doctors were also involved in the 'depth interrogation techniques' in Northern Irelan de considered as torture by the European Commission of Human Rights Committee $(18,19)$.

With respect to the last few decades, increasing evidence indicates that doctors are frequently involved when torture is carried out $(20,21,22)$. Furthermore, in countries that still enforce the Islamic Sharia laws, the full spectrum of atrocities associated with judicial torture prevails.

\section{Medical ethics in relation to torture}

Right from the beginnings of the medical profession it was realised that the special relationship between the healer and the individual seeking help was open to abuse. Medical ethics were developed - the Hippocratic oath and the teaching of Moses Maimonides are examples. Both of these stated in essence that no considerations except the interests of the patient may enter into the relationship (23). These oaths were known during the following millennia, but no penalties seem to have been exacted when doctors participated in judicial torture.

There are a number of possible explanations. The torture was performed according to the law, and perhaps the doctors regarded the law as being above medical ethics. The act of torture might also not have been seen as part of a doctor/patient relationship at all. The doctor was acting at the request of the state, and not of the patient, and so the victims could not subsequently invoke the principles of medical ethics. The latter argument has its proponents even today (24).

During the Nazi era, medical ethics no longer 
applied to individuals. The changed concepts legitimised torture and the annihilation of the infirm, the mentally retarded, and the healthy alike. The methods were developed partly by the medical profession and they were frequently carried out with the direct participation of medical doctors (25). Furthermore, doctors directly conducted pseudoscientific experimentation in the form of medical torture, and this was freely reported in the medical press (12).

After the war, a movement was set in motion that focused medical ethics once more on the individual patient. Yet the difficulty in delimiting definitions of abuse continued. In Northern Ireland 'depth interrogation' methods were employed in the struggle against the IRA, and when such practices were questioned, the official reports stated $(26,27)$ :

'If torture becomes inevitable it is necessary to humanise it and have an attending physician to moderate it, and even stop it if, in his medical opinion, it becomes physically dangerous'.

Statements like the above and well-documented examples of doctor involvement in torture, such as the case of Steve Biko, considerably raised awareness of the issue (28).

With the adoption of the Tokyo Declaration by the World Medical Association (1975), and the Principles of Medical Ethics by the United Nations (1982), it was agreed that all forms of doctor participation in torture were unethical.

The adoption of the Declarations was unanimous; however, it carried no obligation for the adopting governments. In fact, some of the governments were totalitarian at the time of adoption and others later became completely out of touch with democratic traditions.

Three examples serve as an illustration:

1) The difference of focus between the UN Principles of Medical Ethics and the doctor's oath in the USSR is evident, the latter itself being a new edition of the Hippocratic oath (20). Apart from the re-definition of key concepts in the oaths, it has also been questioned to what extent totalitarian governments inform the health profession of the content of the new declarations (29).

2) Abuses of human rights have taken place on a large scale in Uruguay and Chile, despite both countries having signed a large number of international declarations that condemn such infractions, including doctor participation in torture $(30,31)$.

3) Arab states that observe the Sharia also adopted the UN Principles of Medical Ethics, despite incongruities in areas such as punishment.

\section{Torture and the law}

Torture as a concept is mentioned in only a few national penal codes. Acts which fall under the concept of torture must consequently be prosecuted according to sections of the law relating to other acts, for example rape, assault with intention to do bodily harm, etc. In addition, national law has on occasion been used to oppose medical ethical evaluations and subsequent sanctions by medical associations (32).

A major development has nevertheless been the adoption of the UN Convention Against Torture of 1984. This convention, which is legally binding for signing parties, entered into force in 1987 after it had been ratified by twenty nations. Several points are stressed, including the duty of ratifying states to:

'Prosecute perpetrators and their accomplices according to the principle of universal prosecution (Article 5), inform and teach about torture, including the medical profession, about torture' (Article 10).

National law, however, reflects the surrounding society, and with a totalitarian governmental system the law may even be an instrument to impede progress in medical ethics, for example by $(1,32,33)$ :

- Rendering previous parts of the law invalid;

- hindering the giving of testimony by doctors accused of involvement in torture;

- dissolving national medical associations and thereby their ability to deal with aggressors, and

- the use of 'show trials' to exonerate the offenders.

Yet concepts are perceived differently by different cultures, and even by different countries whose cultural backgrounds are otherwise similar. The socalled grey areas of medical ethics may illustrate this.

\section{Islamic punishment}

Certain Islamic forms of punishment, for example whipping and the severing of hands, have been labelled as torture. UN Declarations and Conventions, however, exclude such punishments from definitions of torture because they are 'lawful sanctions'. This provision, however, does not exist in the Tokyo Declaration. Thus, doctor participation in, for example, whipping, as stipulated in the Whipping Ordinance of Pakistan, would be legal by national and international legal standards, but unethical by international moral standards (35). The Islamic Code of Medical Ethics (Kuwait 1981) does not address this issue.

Two opposing views are taken in relation to Islamic punishments: they are morally wrong and should always be condemned, or they are religious in origin and so cannot be questioned. However, as a possible alternative to such extreme views, there is the basic Islamic idea that punishment according to the Sharia can only be applied in 'just' societies, ie only in societies in which all members are provided with sufficient means to lead a decent personal and family life. Few such societies will ever exist. Another 
approach is to view the punishments as pre-Islamic, only taken over by Islam as a means of controlling abuse.

\section{What constitutes torture?}

Torture is a semantic concept that comprises peak moments of intense bodily or psychological pain, or both. In the major declarations and conventions mentioned, for example the Principles of Medical Ethics, the Tokyo Declaration, and the Convention Against Torture, definitions are included and built into the concept of acts of abuse ranging from cruel, inhuman and degrading treatment to outright torture. The European Convention for the Prevention of Torture and Inhuman or Degrading Treatment or Punishment, however, carries no definition and this leads to the newer concept of torture as a process beginning at the time of arrest and ending at the time of death or release of the victim. Furthermore, the circumstances involved in a particular case must also be taken into consideration (34). The reason for the involvement of doctors, however, seems to be the changed purpose of torture. While the purpose formerly was mostly directed towards extraction of information or confessions, or even punishment, the purpose today seems to address such goals only initially. The ultimate aim now is the destruction of the identity of the individual so that on release he or she can serve as a deterrent to others. It is also possible that doctors are involved simply because they are at the place of torture, as conceptualised in the phrase 'Doctors at Risk', pointing to the higher likelihood for doctors to become involved in torture when employed by various authorities that condone torture.

\section{Capital punishment}

The death penalty is still in use in a number of countries, and the months or years waiting for execution are labelled by many as psychological torture. Doctors become directly involved when they are asked to certify mental disease or its absence. The time of execution, and possibly even its cancellation, may be affected by the doctor's involvement $(36,37,38,39)$. No consensus has been reached, and the 1990 Conference on Security and Co-operation in Europe (CSCE) confirmed that there was disagreement about the doctor's role in capital punishment. The law may compel doctors to participate, but their acts are deemed unethical by their peer groups nationally, for instance as stated by the American Medical Association, or internationally, as expressed in the statements on capital punishment by the World Medical Association (40,41).

\section{Incommunicate detention}

Long-term detention in isolation is very stressful, particularly for some types of individuals, and has been labelled psychological torture. Yet medical doctors are supposed to evaluate whether the individual prisoner can tolerate such isolation. This is an offence, according to the UN Standard Minimum Rules for the Treatment of Prisoners and Related Conditions (1955, 1977) (42).

\section{Abuse of psychiatry}

This subject, which is well described and documented, was the driving force behind the adoption of the Hawaii Declaration $(1977,1983)$ by the World Psychiatric Association $(43,44)$. Abuse of psychiatry for political reasons has been documented particularly in communist countries, but following international pressure it now seems to be used less. It is noteworthy that dissidents and psychiatric patients alike are affected by the abuse. Furthermore, psychiatric treatment necessarily reflects the surrounding society and in this way gives an insight into the working methods of repression (29). The USSR was expelled from the World Psychiatric Association in 1983, but was re-admitted in 1989 (45).

\section{Dissent}

With respect to participation in torture, most doctors are compelled to adhere to modern medical ethics. This is because of their membership of national medical associations, because of the Tokyo Declaration, or because their governments have adopted the Principles of Medical Ethics. A few doctors, however, still argue for the use of torture for reasons based on utilitarian philosophy and argue fos the involvement in the torture of whatever skills may be necessary to achieve the desired goal $(24,46,47)$.

\section{Participation in torture}

Participation may be thought of as including a range of actions from the direct monitoring of torture sessions to the doctor's mere presence on the premises where torture is taking place (48). The use of medical skills to develop new torture methods is included within this range of actions. The point at which presence on the premises becomes participation is difficult to define: it will be a subject of concern for future tribunals. These will also have to consider mitigating factors, for example acts carried out under threats to life.

\section{Prophylactics}

Acknowledging that there are a limited number of topics where agreement has not been reached, actions have been taken to deal with the main issue. Such actions may be expressed in prophylactic steps, which encompass:

Primary prophylactic, ie the prevention of torture, for example by making it illegal everywhere, for example the Convention Against Torture by the UN.

Secondary prevention, ie preventing doctors from becoming involved. To this end, national and international medical ethical standards have been developed and are included in medical curricula (49). Knowledge is also disseminated through international 
medical meetings, and a number of established national and international organisations have now become involved in the subject, for example the British Medical Association (50).

Tertiary prophylactic is the prosecution of perpetrators. This may be done individually by the legal system or by doctors' disciplinary bodies, ie licensing bodies or medical associations. Only the latter, however, have to some extent been successful in their attempts $(48,51)$. Finally, doctors may be attacked collectively through pressure on their national medical associations, as for example when the USSR was expelled from the World Psychiatric Association.

As a consequence of the above, the recommendations of the meeting in Tromsø centred on the understanding that a large number of declarations had been adopted and that the present need was for more implementation.

The recommendations therefore highlighted the need for:

\section{1) An international tribunal}

As national legal systems and disciplinary bodies may be impotent during periods of repression there was a call for a standing international tribunal. It was suggested that the Montevideo group, comprising the Medical Association of Uruguay, the Danish Medical Association, and the Rehabilitation and Research Centre for Torture Victims (RCT) should initiate the process, and that the group should perhaps be extended later to include other members. The tribunal should secure support from international medical and legal bodies.

\section{2) A clearing house}

Names of doctors convicted by their national medical associations of participation are already in circulation (52). A body is needed for the collection and dissemination of these names. The meeting recommended that the RCT should initiate this process.

\section{3) Ethical and legal development}

This subject still needs development to secure a system that will encompass all cultures. For the time being it was recommended that the Tokyo Declaration should be accepted in all national codes of ethics.

But developments are needed in ethics insofar as some doctors claimed that what they did was correct, and only during later periods were they evaluated differently.

Finally, a duty to report colleagues involved in torture was emphasised, either to a national medical body or to an international association.

\section{Motivation for doctors to participate in torture}

Doctor participation in torture during the present century was initially discussed in terms of the psychopathology of a few deranged individuals. Later evidence, however, points to large-scale involvement.

Whatever personal motives may lie behind acts of individuals, the organisation of a repressive system itself seems far more important. This form of involvement is implicit in the concept 'Doctors at Risk', which refers, for instance to doctors employed by the state in the military, in the police, as district surgeons, or as forensic pathologists (1).

\section{Conclusion}

There is documentary evidence that doctors throughout the history of medicine have participated in both judicial and illegal forms of torture. Individual factors may have been of importance for motivation, but far more important seems to have been the organisation of the system. Involvement of doctors in torture is an issue that attracted little attention before the conclusion of World War II. Since then a number of declarations and conventions have been adopted, stating in essence that torture can never be permitted in 'real life situations', thereby disregarding dissent based on utilitarian philosophy.

Action is needed to curb participation, and if the issue is analysed in prophylactic terms, the primary and secondary prophylactics are of increasing importance.

However, transgressors must also be punished an for this to happen a standing tribunal is needed, as we as a clearing house for the names of the doctors found guilty of participation in torture.

Medical ethics should be upgraded. However, it may very well be that the understanding of the issue and the need for upgrading the ethics differ, despite the maxim: 'PRIMUM NON NOCERE'.

Peter Vesti, MD, is a psychiatrist at the Rehabilitation and Research Centre for Torture Victims in Copenhagen, Denmark and Niels Fohan Lavik, MD, is Professor of Psychiatry at the Psychosocial Centre for Refugees at the University of Oslo, Norway.

\section{References}

(1) Doctors, ethics, and torture. Proceedings of an International Meeting, Copenhagen, August 1986. م Organised jointly by the Danish Medical Association and the Rehabilitation and Research Centre for Torture Victims. Danish medical bulletin 1987; 34: 185-216.

(2) Rasmussen O V, Pagaduan-Lopez J, Udsen P, Esperson O. Doctors involved with torture. Lancet 1988; i: 1112.

(3) Mettler C C, Mettler F A, eds. History of medicine. Philadelphia, Pa: Blakiston Company, 1947.

(4) Stiassny S. Die pfählung. Eine forme der todesstrafe: kultur- und rechtshistorische studie. Vienna: 1903.

(5) Peters E. Torture. New York: Basil Blackwell, 1985.

(6) Langbein J H. Torture and the law of proof: Europe and England in the Ancien Regime. Chicago, Ill: University of Chicago Press, 1977.

(7) Scott G R. The history of torture throughout the ages. London: Torchstream Books, 1951. 
(8) Mitscherlich A, Mielke F, eds. Medizin ohne menschlichkeit. Frankfurt am Main: Fischer Taschenbuch Verlag, 1985.

(9) Morimura S, Shimozato M. The devil's gluttony. Tokyo: Banseisha, 1982.

(10) Mitscherlich A, Mielke F. Doctors of infamy. New York: Henry Schuman, 1949.

(11) Maretski T W. The documentation of Nazi medicine by German medical sociologists. Social science and medicine 1989; 29: 1319-1332.

(12) Hanauske-Abel H M. From Nazi holocaust to nuclear holocaust: a lesson to learn. Lancet 1986; ii: 271-273.

(13) de Beauvoir S, Halimi G. Djamila boupacha. Paris: Gallimard, 1962.

(14) Anonymous. The gangrene. New York: Lyle Stuart, 1960.

(15) Hinkle L E, Wolff H G. Communist interrogation and indoctrination of 'enemies of the state'. Analysis of methods used by the Communist State Police (a special report). Archives of neurology and psychiatry: section on neurology 1956; 76: 115-174.

(16) Forest E. Testimonios de lucha y resistentia. Barcelona: Editiones Mugalde, Gnenoveva Forest Tarrat, 1977.

(17) Sagan L A, Jonsen A. Medical ethics and torture. New England journal of medicine 1976; 24: 1427-1477.

(18) Wade N. Technology in Ulster: rubber bullets hit home, brainwashing backfires. Science 1972; 176: 1102-1106.

(19) Lippman $M$. The protection of universal human rights: the problem of torture. Universal human rights 1979; 1: 25-55.

(20) Stover E, Nightingale E O, eds. The breaking of bodies and minds: torture, psychiatric abuse and the health professions. New York: Freeman, 1985.

(21) Rasmussen O V. Medical aspects of torture: torture types and their relation to symptoms and lesions in 200 victims, followed by a description of the medical profession in relation to torture. Thesis. Danish medical bulletin 1990; 37 (supplement 1): 1-88.

(22) Vesti P. Extreme man-made stress and anti-therapy. Danish medical bulletin 1990; 37: 466-468.

(23) Broadie A. The moral philosophy of Maimonides. Fournal of medical ethics 1988; 14: 200-202.

(24) Bennun M. Doctors, torture and the law: a South African case study. Radical community medicine 1985; 20 : $30-40$.

(25) Lifton R J. The Nazi doctors: medical killing and the psychology of genocide. New York: Basic Books, 1986.

(26) Lord Parker of Waddington. Report of the committee of privy counsellors appointed to consider authorised procedures for the interrogation of persons suspected of terrorism. London: HMSO, 1972. (Cmnd 4901)

(27) Wilson L L. Torture, doctors and the World Medical Association. Medical journal of Australia 1983: 236-239.

(28) Rayner M. Turning a blind eye? Medical accountability and prevention of torture in South Africa. Washington DC: American Association for the Advancement of Science (AAAS). Committee on Scientific Freedom and Responsibility, 1987.

(29) Gluzman S. On Soviet totalitarian psychiatry. Amsterdam: CIP-Gegevens koninklijke bibliotheek, 1989.

(30) Goldstein R, Gelhorn A. Human rights and the medical profession in Uruguay since 1972. New York: AAAS.
Committee on Scientific Freedom and Responsibility, 1982.

(31) Amnesty International. Chile: evidence of torture. London: Amnesty International Publications, 1983.

(32) Vesti P, Espersen O. Ethico-legal developments as a consequence of medicine in the service of repression: acceptance and resistance. Nordic journal of international law (in press).

(33) Ronaghy H A. Persecution of doctors in Iran. Lancet 1986; ii: 518.

(34) Suedfeld P, ed. Psychology and torture. New York: Hemisphere Publishing Corporation, 1990.

(35) New Islamic laws. Lahore: Mansoor Book House, 1987.

(36) Appelbaum P S. Competence to be executed: Another conundrum for mental health professionals. Hospital and community psychiatry 1986; 37: 682-684.

(37) Kevorkian J. Medicine, ethics, and execution by lethal injection. Medical law 1985; 4: 307-313.

(38) Casscells W, Curran W J. Doctors, the death penalty, and lethal injections: recent developments. New England journal of medicine 1982; 307: 1532-1533.

(39) Bolsen B. Strange bedfellows: death penalty and medicine. Fournal of the American Medical Association 1982; 248: 518-519.

(40) Kemperman C J F. Medical involvement in capital punishment. Lancet 1983; i: 301-302.

(41) Amnesty International. Ethical codes and declarations relevant to the health professions. London: Amnesty International Publications, 1985.

(42) Daly R J. Effects of imprisonment and isolation. In: Pichot P, Berner P, Wolf R, Thau K, eds. Psychiatry: the state of the art: drug dependence and alcoholism, forensic psychiatry, military psychiatry (vol 6). New York: Plenum Press, 249-254.

(43) Bukovsky V. To build a castle: my life as a dissenter. London: André Deutsch, 1978.

(44) Podrabinek A. Punitive medicine. Ann Arbor, Mich: Karoma Publishers, 1980.

(45) Koryagin A. World psychiatry: readmitting the Soviet Union. Lancet 1988; ii: 268-269.

(46) Twining W L, Twining P E. Bentham on torture. Northern Ireland legal quarterly 1973; 24: 305-356.

(47) Jones G E. On the permissibility of torture. Fournal of medical ethics 1980; 6: 11-15.

(48) Stover E. The open secret: torture and the medical profession in Chile. Washington, DC: AAAS. Committee on Scientific Freedom and Responsibility, 1987.

(49) Sørensen B, Vesti P. The consequences for medical education of implementing the United Nations Convention against Torture and the European Convention for the Prevention of Torture. Medical education 1990; 24: 467-469.

(50) British Medical Association. The torture report. Report of a working party of the British Medical Association investigating the involvement of doctors in torture. London: BMA, 1986.

(51) Bloche M G. Uruguay's military physicians: cogs in a system of state terror. Washington, DC: AAAS. Committee on Scientific Freedom and Responsibility, 1987.

(52) Martirena G. Uruguay. La tortura y los medicos. Montevideo: Banda Oriental, 1987. 